Redo M. (2015). The importance of prudential regulations in the process of transmitting monetary policy to economy. Copernican Journal of Finance \& Accounting, 4(2), 145-158. http://dx.doi. org/10.12775/CJFA.2015.021

\author{
Magdalena Redo* \\ Nicolaus Copernicus University
}

\title{
THE IMPORTANCE OF PRUDENTIAL REGULATIONS IN THE PROCESS OF TRANSMITTING MONETARY POLICY TO ECONOMY
}

Keywords: central bank, monetary policy, macroprudential supervision, mechanisms of transmitting impulses of monetary policy.

J E L Classification: E58, E52, G28, E51.

Abstract: The main aim of prudential regulations is to increase the stability of financial systems; however, such regulations also increase the risk-taking tendency of banks, they encourage them to combine and limit their lending possibilities with, at the same time, lowering the efficiency of monetary policy in affecting economic processes. Thus, it occurs as a reasonable solution to integrate macroprudential supervision with monetary policy of the central bank and to subsequently limit the pro-cycle character of these regulations.

The aim of this article is to discuss the importance of the regulatory channel in the process of transmitting impulses of monetary policy into economy and to overview the results of research, which analyzed the influence of macroprudential regulations on bank lending policy as well as their sensitivity towards monetary policy of the central bank.

Translated by Magdalena Redo

Date of submission: December 18, 2014; date of acceptance: February13, 2015.

* Contact information: allmagda@wp.pl, Faculty of Political Sciences and International Studies, Nicolaus Copernicus University, Batorego 39L, 87-100 Toruń, Poland, phone: +4856 6112137 . 


\section{INTRODUCTION}

The mechanism of transmitting impulses of monetary policy can be described as activities of economic entities resulting from the policy of the central bank (Kokoszczyński 1999, 8).

The central bank, with help of its instruments, has a possibility of influencing the course of economic processes for realizing its basic aim - ensuring stability of prices and, thanks to that, stability of production. Due to the complexity and changeability of economic processes, reaction of economic entities towards changes in interest rates of the central bank is conducted in different ways (by transmission channels). Traditional channels of transmission include an interest rate channel, credit channel and an exchange rate channel (Demchuk, Łyziak, Przystupa, Sznajderska, Wróbel 2011). However, the on-going economic development, processes of internationalization, globalization, development of finance markets, and more detailed research of mechanism of transmission led to pointing to other important ways (channels) in which monetary policy of the central bank influences economy (production and level of prices) and they visualize complexity of traditional channels as well as numerous links between those.

The following scheme presents a synthetic approach to transmission channels of monetary policy, with which central banks influence activities of economic entities, the scope of production and levels of prices. It allows for an overall view on contemporary knowledge about complexity of processes of transmitting impulses of monetary policy into economy and highlights, aside from the traditional channel of interest rates, credit channels and channels of assets prices. It also highlights the importance of the influence of monetary policy on the scope of lending and on the price of marketable assets for economic processes, and also on the effectiveness of transmission mechanisms (scheme 1; Redo 2013). 
Scheme 1. The channels of monetary transmission

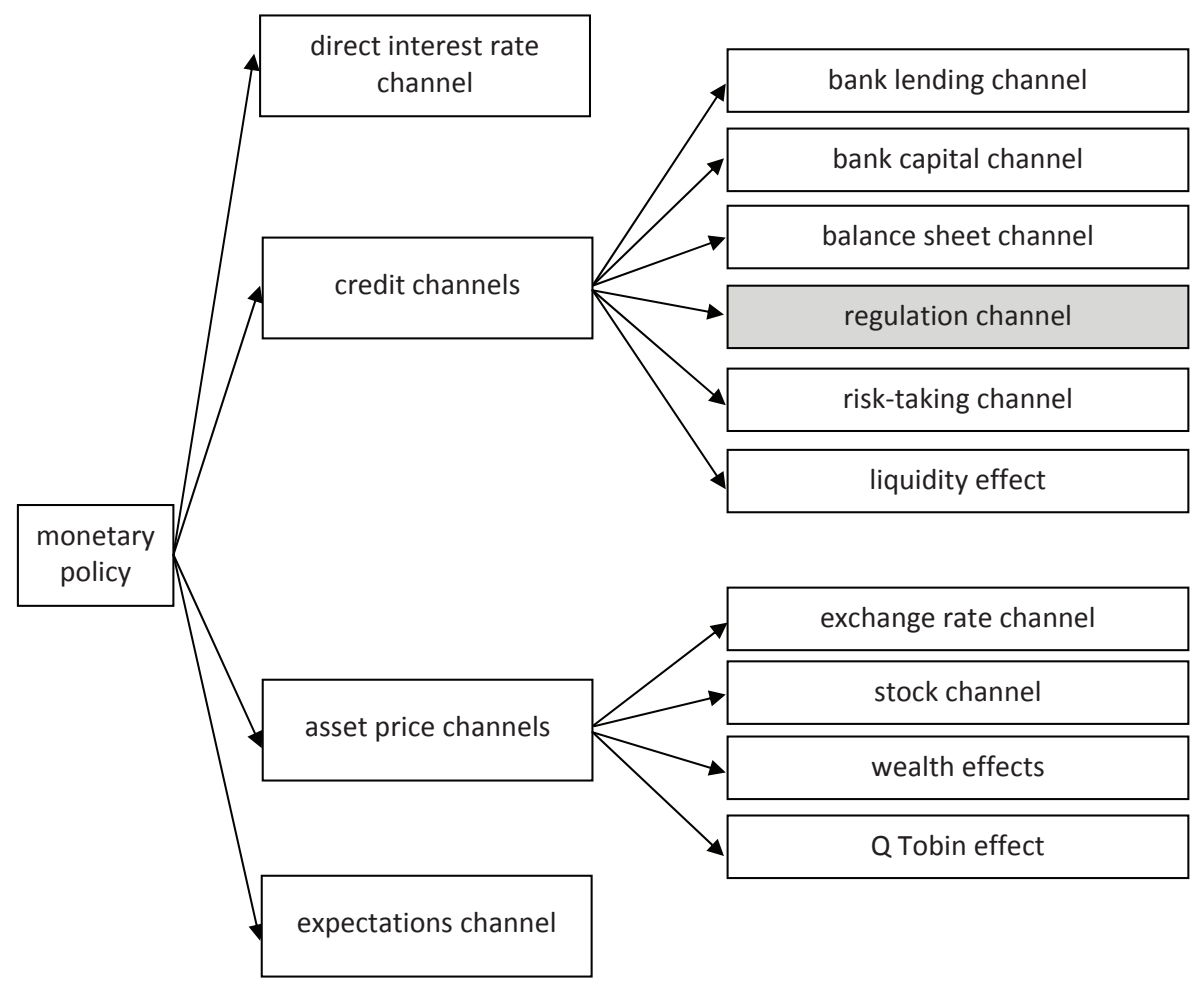

S o u r c e : self-reported data on the basis of Mishkin, 2007, Boivin, Kiley, Mishkin, 2010, Mishkin, 2001 and Bank of England, 2014.

\section{THE RESEARCH METHODOLOGY AND THE COURSE OF THE RESEARCH PROCESS}

The article is a critical analysis of literature, reports and the results of econometric studies concerning the impact of prudential regulation on banks' functioning and the process of transmitting monetary policy into the economy. There have been used induction method and comparison method. 


\section{REGULATORY CHANNEL IN THE PROCESS OF TRANSMITTING MONETARY POLICY ${ }^{1}$}

Due to the lack of general agreement regarding expansion of monetary policy's aims and making it responsible for preventing financial instabilities, mainly providing more restrictive monetary policy (leaning against the wind) which would prevent excessive loan actions, especially in the face of high increase of prices on the assets' markets of entities which are the most susceptible towards speculative bubble, macroprudential regulations became the main tool for preventing the aforementioned. Regulations for financial institutions, for instance capital requirements of the Basel Committee on Banking Supervision and European Banking Supervision (introducing financial leverage ratio, shortterm liquidity norm, redefining classes of liquid assets) or the level of the reserve requirement and its interest rate (importance of which has become marginalized, especially in the Western countries, due to popularity of the Basel regulations in the $90^{\prime}$ s of the $20^{\text {th }}$ century) greatly influence the scope of the bank capital channel, their risk-taking channel and the bank lending channelthus, they influence functioning of the mechanism of transmitting monetary policy into economy and its efficiency.

Capital regulations cause the increase of costs in functioning of banks due to the necessity of meeting them (the fear of exceeding limits forces them to undertake costly preventing actions) and they greatly influence the way of observing, managing and evaluating risk by these banks (and so they influence the tendency to risk-taking and functioning) - Borio, Zhu 2008. They also greatly limit the possibilities of issuing loans by banks, which is proved by the results of empirical studies. They also cause lowering of banks' profits and the amount of their capital; encouraging banks to connect may cause higher concentration of the banking sector (Chami, Cosimano 2001). As Bernanke, Low (1991) indicated, Regulations of the Basel Committee of Banking Supervision from 1988 (Basel I) contributed to a significant limitation of supply of loans in the recession period of 1990-91 in the USA (credit crunch), much greater than in the case of banks not subject to these regulations (Peek, Rosengren 1993). The relation

1 It played an essential role in the USA in the process of transmitting monetary policy by influencing the supply of loans in the beginning of the 80's of the $20^{\text {th }}$ century when government regulations and Regulation Q were significantly shaping the market of mortgage loans (McCarthy, Peach 2002; Brayton, Mauskopf 1985). 
between issuing the aforementioned capital regulations and the lowering of the loans' supply in the United States was also confirmed by, for instance, Peek, Rosengren (1992) and Hancock, Wilcox (1992) or Wagster (1999); Breeden, Issac (1992) even advocated abolishing Basel I regulations by accusing them of crashing the loans' action in the United States in $90^{\prime}$ 's of the $20^{\text {th }}$ century. Berger, Udel (1994) also added that capital regulations of Basel I may be partially responsible for the decrease in the supply of loans. Wagster (1999) indicated also one economically significant effect - strong relocation of the capital from loans to government bonds in banks not only within the United States but also in Canada and Great Britain (due to the Basel I regulation, loans required $8 \%$ of capital safety, and treasury bonds only the maximum level of $1.6 \%$ ). It was confirmed by Furfine (2001), who pointed out a significant decrease of the share of commercial loans within the banks' wallets in the contrast to treasury bonds. Borio, Zhu (2008) also pointed that prudential regulations strengthened the activity of the risk-taking channel and also that the influence of capital and supervisory regulations on the financial system and the course of the business cycle increased. Peek, Rosengren (1997) indicated that the commercial sector of real estate is very sensitive towards capital regulations of banks; Hancock, Wilcox (1997) showed that crediting of commercial real estates in the USA is much more sensitive towards the capital shock of banks than crediting for housing (which is, partially, an effect of the political support of developing house-building). As Boivin, Kiley, Mishkin (2010) show, the past decades brought a number of regulatory changes, especially with respect to mortgage loans which made them more coupled with the interest rate and less coupled with creditworthiness.

Watanabe (2007) indicated that the Basel I regulations in terms of capital adequacy issued in Japan from March 1993 also contributed in the following years to a great decrease in the loans' supply. Peek, Rosengren (1997) pointed that these regulations contributed also to a great decrease in the loans' supply for the Japanese banks in the USA (harsher capital requirements were used in this case); these banks, in the culmination moment in the 90's of the $20^{\text {th }}$ century were creditors of $18 \%$ of manufacture and trade loans in the USA (in 1988 all of the 10 biggest banks around the world had their headquarters in Japan). These conclusions were confirmed by Ito, Nagataki Sasaki (1998), who indicated that capital regulations greatly influenced the lowering of credit actions of active banks on foreign markets, which were subject to harsher limitations. Economic Planning Agency (1998) indicated that the tendency to 
issuing loans in Japan is more sensitive towards capital regulations than regulations on the quality of assets. Limiting the supply of loans on the basis of issuing capital regulations of the Basel Committee of Banking Supervision is observed also in developing economies. Choi (2000) confirmed that issuing regulations regarding capital adequacy in the $90^{\prime}$ 's of the $20^{\text {th }}$ century in Korean banks caused the decrease of tendency for issuing loans. Chiuri, Ferri, Majnoni (2001) documented decrease in the supply of loans by analyzing 16 rising economies which implemented Basel I regulations in the 90 's in the $20^{\text {th }}$ century. They also showed that the phenomenon was much stronger in banks with lower capitalization. Jackson et al (1999) pointed that regulations caused the increase in capital adequacy ratio, especially among banks with lower capitalization, and the improvement takes part due to financial activities which are more attractive for the bank at the given time - in the period of good business cycle it is more likely to happen due to the increase in the bank's own capital (because of higher risk and cheaper emission of shares), and at the time of crisis through limiting credit actions. Tanaka (2002) points that capital regulations are a crucial determining factor when it comes to sensitivity of the supply of loans on interest rates; thus, Basel II regulations may lead to a higher decrease of the loans' supply in the situation of higher credit risk ; they may also limit the efficiency of monetary policy as a tool for stimulating economic growth in the time of recession.

Although reserve requirement nowadays has a small role in stabilizing the financial sector also in many developing economies (but not in all, for example in China it is about $20 \%$ and is actively used to fight inflation), it has occurred due to the current financial crisis that it is a powerful tool of the influence that monetary policy of the central bank has on the financial situation of banks and the loans supply. It is confirmed by Montoro, Moreno (2011), who pointed negative relationship between the changes in the level of reserve requirements (increase and decrease during the crisis of 2007) in Brazil, Colombia and Peru, and the loans supply. Mesquita, Toros (2010) pointed also that the aforementioned reduction of reserve requirement in Brazil contributed to re-establishing financing small financial institutions which were hurt the most due to the decrease of country's liquidity. Herrera, Betancourt, Varela, Rodriguez (2919) showed that the changes regarding the level of reserve requirement contributed to strengthening of the actions of the direct channel of interest rates in Colombia; they also pointed that lowering the reserve requirement generates a stronger reaction of the market's interest rates than its increase. 


\section{REGULATION DIRECTIONS}

Maddaloni, Peydró (2010) underline that the existing financial crisis forces new duties on central banks - the necessity of conducting macroprudential supervision to monitor system risk. Before the crisis, Rajan (2005) had indicated the crucial increase of the risk tendency in the financial world and he also pointed to the increase of danger for economies due to disturbances in the functioning of financial sector in the future; he suggested that it should be reflected in monetary policy and supervisory activities which should limit tendency to risk-taking in financial institutions. Keys, Mukherjee, Seru, Vig (2008) also underlined the necessity of improving functioning of mechanisms of testing creditworthiness and better clarity with respect to securitization. They also suggested differentiating between securitization for assets with poorer and richer sources of information (as an effect of the more thorough evaluation of credibility). Purnanandam (2009) pointed that bigger problems in the situation of a shock have banks with low capitalization and lower share of deposits on demand, pointing at the same time to the direction of developing regulations for financial risk and capital ratio of banks. Also Farhi, Tirole (2009) underline the importance of the macroprudential supervision and suggest that optimum regulations should be in the form of minimum liquidity requirements combined with monitoring of the quality of liquid bank assets. Dell'Ariccia, Laeven, Suarez (2013) point that, in order to acquire stability of prices and financial stability, it is essential to integrate macroprudential regulations with monetary policy. Although tightening of the monetary policy in the connection with good business cycle may contribute to the realization of both aims (it will decrease the inflation pressure and the tendency to risk-taking), in the situation similar to the one before the crisis of 2007/08 with low inflation and exceeding tendency to risk-taking, tightening of the monetary policy would limit risk-taking, but it would cause an undesired decrease in economic activity and/or cause deflation. That is why, in such case, it is necessary to use regulatory tools in close coordination with monetary policy of the central bank, which serves as a strong argument for the centralization of the macroprudential supervising by the monetary power.

\section{CHARACTER OF REgULATIONS}

The latest research (for example Geneva Report on World Economy 2009) indicate that regulations must be counter-cyclical, meaning they should be harsher 
in the times of good business cycle, and looser in the period of economic stagnation. However, Rajan (2009) points that capital regulations contributed, in the period of good business cycle before the crisis of 2007, to transferring bank activity towards unregulated financial mediation (what, paradoxically, deepened the crisis), and not to creating better stability. Thus, he indicates that it is crucial to focus on creating regulations, which sustain fluctuations of business cycle, instead of arguing about too high or too low level of regulating activities of financial institutions. Aliaga-Díaz, Olivero, Powell (2011) pointed that countercyclical regulations of Basel III from 2010 (implying the improve of the quality of assets and capital buffer) did not bring any spectacular advantages because banks had already kept the higher level of required capital ratio (capital buffer - exceeding requirements of Basel III) in case of future shocks. Additionally, banks accurately anticipate the possibility of lowering the capital buffer in the period of worse business cycle; thus, they reduce counter-cyclical regulatory activities. For example, in Brazil, Mexico and Colombia they indicated that these economies were hurt due to the last financial crisis on much lower level due to high capital buffers kept on the level significantly exceeding regulatory requirements (it could be said that a number of past crises has become a lesson learned for financial institutions) proving at the same time, that, although counter-cyclical regulations of Basel III contributed to limiting consumption fluctuation, they increased investment fluctuation (because of too fast limiting of the capital buffer). Also Zicchino (2005) pointed to the pro-cyclical activity of capital regulations. It must be noted, however, that the monetary power also has the possibility of mitigating the pro-cyclical influence of macroprudential regulations. Cecchetti, Li (2005) indicate that Blum, Hellwig (1995) were the first to show that capital regulations may tighten fluctuations of the business cycle; however, their analyses do not include the possibility of mitigating the effects by the monetary policy. That is why, it is suggested that monetary policy should react more strongly in the situation of shrinking of banks capitals, which will weaken the pro-cyclical influence of prudential regulations and maybe even neutralize the influence. It was also indicated by them that FED in the $90^{\prime}$ s of the $20^{\text {th }}$ century led the monetary policy according to the aforementioned theory and lowered interest rates more significantly in the situation of bank shock; at the same time, it weakened the pro-cyclical character of bank regulations introduced in the 80's, contrastively to the policies of central banks in Germany or Japan in the 80's. (Cecchetti, Li 2005). This serves as an- 
other important argument for coordinating the macroprudential supervision with monetary policy.

\section{REGULATIONS IN DEVELOPING COUNTRIES}

It needs to be pointed out that the majority of research is conducted in developed economies- their financial system is significantly different from the one in developing countries. That is why, it is essentially important to devote more attention to development and modification of tools for modeling mechanisms of transmitting monetary policy in developing countries, which will take into consideration its specificity (Agénor, Pereira da Silva 2011). Agénor, Alper, Pereira da Silva (2012) pointed that, in the case of developing countries, it is a much better solution to provide regulations limiting the increase of credit actions and excessive risk, than to tighten monetary policy in the situation of inflation pressure because of high risk of the flow of capital from abroad which may cause the credit boom, the increase in the prices of assets and the strengthening of the currency and, at the same time, worsen attractiveness of the economy and worsen the deficit on the current account. Increasing flow of growing capital around the world, extending stagnation in Western economies, low interest rates (and profitability of investments relying on such), as well as quantitative loosening conducted by the biggest central banks cause an increased flow of capital to some economies (the so-called sudden floods). The flood of capital, which came to the countries of Latin America within the years of 2009-2011, caused the credit boom and fear of the bubble's crack due to fragile financial and economic stability of the region.

However, the problem is also found in highly-developed economies. Within the last years, also small-developed economies such as Switzerland, Sweden or Australia, which issue exchange reserves that, are alternative for dollar or euro became beneficiaries of huge flow of capital. Thus, the aforementioned may (or even should) significantly strengthen the importance of regulatory channel in these countries at a cost of a direct channel of interest rate (Agénor, Alper, Pereira da Silva 2012). There is a need to show the other side of the coin. In the case of developing economies, where banks are the only financial middlemen, the regulations' effect may be totally different from the one that is expected. As Chiuri, Ferri, Majnoni (2001) point out, capital regulations, instead of creating advantages due to reducing bad credits, may lead to decrease in banks fluidity and to decrease in economic activity. 


\section{CoNCLUSIONS}

Prudential regulations, which are to increase the stability of financial systems and economies, increase also the risk-taking tendency of banks and encourage them to search for higher profits on dynamically developing financial markets and the resign from crediting common economic entities - the realistic economy. These regulations lead banks also to combining and creating huge capital groups, with at the same time limiting efficiency of functioning of the banking sector and the entire financial sector, including economies. They also limit possibilities of banks to give credits, so the entire credit action itself is limited and the possibilities of development of the entire economy are limited - it may be especially noticed in economies where the banking sector is a dominant one. The level of capital in banks is one of the major factors determining sensibility of credit supply towards interest rates. Thus, all regulations in this area limit efficiency of monetary policy as a tool for stimulating economic growth. It does not mean, however, that it is necessary to resign from them. A just solution would be to integrate macroprudential regulations with monetary policy. Although restrictive monetary policy in the times of good business cycle is able to weaken the risk-taking tendency and inflation pressure, in the situation when exceeding risk-taking tendency is accompanied with low inflation (for example before the crisis of 2008), tightening of monetary policy could lead do deflation (and unwelcomed decrease of the economic growth). Thus, it serves as a strong argument for coordinating regulation tools with monetary policy. As Dell'Ariccia, Laeven, Suarez (2013) show, it is also a strong argument for centralization of the macroprudential supervision within the scope of monetary power. Additional argument for would be the pro-cyclical effect of regulation, which monetary policy may try to decrease or even neutralize through stronger reaction of central banks in the situation of bank shocks.

Development of the regulations themselves is necessary. From the point of efficiency of monetary policy's actions towards economy, apart from limiting their pro-cyclical character, studies also show the necessity of stronger quality control, control of flow of assets, more clarity in securitization process as well as weakening the risk-taking tendency of financial institutions which is, paradoxically, increased by regulations (more at Redo 2013). It also must be indicated that the majority of research analyzing the effects of prudential regulations are conducted in highly-developed economies - their financial systems significantly differ from the ones in developing countries. That is why it is necessary 
to explore the effects of implemented and developed regulations in less-developed economies - also in Poland, where banks are also very often lower capitalized and, as the results of the studies show, the credit supply is more sensible towards regulations what may significantly affect possibilities of development or surviving crises.

This issue is additionally worsened by the increasing consolidation of the banking sector on the international scale, which allows for easier movement of the capital - as an effect, weaker economies will be subject to a more intense phenomenon of credit crunch and a problem with efficiency of transmitting monetary policy, which aims at increasing the economy. Thus, it would be advisable to think about modifying such regulation, which would enable for protecting weaker economies, which, in situations of crisis, are unfortunately susceptible towards outflow of capital and escalation of the aforementioned phenomena.

Prudential regulations and supervisory activities are affecting more and more the financial system and the functioning of economy. It partially corresponds to the changes in perceiving and evaluating risk and the higher sensitivity towards capital requirements. Carney (2009) indicated that it is advisable to keep in mind that implementing prudential regulations will influence the mechanism of transmitting monetary policy and thus it will change identified effects of using instruments of monetary policy.

It appears that now it is too late, but when the next crisis appears (it will appear, sooner or later), a moment of shock must be used to make politicians from main financial centres to think about the world's future and to implement a broader spectrum and/or more radical limitations for financial institutions (which currently use hundreds of billions of USD). If not, it would be advisable to, at least, implement proper taxation on such institutions and use such means as a source of credits for small and medium businesses which would become a great advantage for 7 billion of people who, from the $80^{\prime}$ s and 90 's of the $20^{\text {th }}$ century, have been victims and not important background for a small group of the world's financiers. Such solution would enable not only for limiting the speed of growth of global imbalances and the scale of future crises, for supporting the world's economic development and mitigation of crises phenomena, but also for increasing the efficiency of monetary policy. 


\section{DEFERENCES}

Agénor, P.R., Alper, K., \& Pereira da Silva, L.A. (2012). Sudden Floods, Prudential Regulation and Stability in an Open Economy. Banco Central do Brasil Working Paper Series, 267, February.

Agénor, P.R., \& Pereira da Silva, L.A. (2011). Macroprudential Regulation and the Monetary Transmission Mechanism. Banco Central do Brasil Working Paper Series, 254, November.

Aliaga-Díaz, R., Olivero, M.P., \& Powell, A. (2011). The macroeconomic Effects of AntiCyclical Bank Capital Requirements: Latin America as a Case Study, Cass Business School City University London, April.

Berger, A., \& Udell, G. (1994). Did risk-based capital allocate bank credit and cause a 'credit crunch' in the United States 1994? Journal of Money, Credit and Banking, $26,585-628$.

Bernanke, B., \& Low, C. (1991). The Credit Crunch. Brookings Papers on Economic Activity, 2, 205-248.

Blum, J., \& Hellwig, M. (1995). The Macroeconomic Implications of Capital Adequacy Requirements for Banks. European Economic Review, 39, 739-749. http://dx.doi. org/10.1016/0014-2921(94)00081-A.

Boivin, J., Kiley, M.T., \& Mishkin, F.S. (2010). How has the monetary transmission mechanism evolved over time? NBER Working Paper 15879, April. http://dx.doi. org/10.2139/ssrn.1783786.

Borio, C., \& Zhu, H. (2008). Capital regulation, risk-taking and monetary policy: a missing link in the transmission mechanism?, BIS Working Papers No 268, December. http://dx.doi.org/10.2139/ssrn.1334132.

Brayton, F., \& Mauskopf, E. (1985). The Federal Reserve Board-MPS Quarterly Econometric Model of the U.S. Economy. Economic Modelling, 2, July, 170-292.

Breeden, R.C., \& Isaac, W.M. (1992). Thank Basel for Credit Crunch. The Wall Street Journal, November 4, A14.

Brunnermeier, M.K., Crockett, A., Goodhart, C.A., Persaud, A.D., \& Shin, H.S. (2009). The Fundamental Principles of Financial Regulation: Geneva Reports on the World Economy 11, Centre for Economic Policy Research, London June.

Carney, M. (2009). Some Considerations on Using Monetary Policy to Stabilize Economic Activity, Federal Reserve Bank of Kansas City.

Cecchetti, S.G., \& Li, L. (2005). Do capital adequacy requirements matter for monetary policy? NBER Working Paper Series, 11830, December.

Chami, R., \& Cosimano, T.F. (2001). Monetary Policy with a Touch of Basel. IMF Working Paper, WP/01/151, October. http://dx.doi.org/10.5089/9781451857030.001.

Chiuri, M.C., Ferri, G., \& Majnoni, G. (2001). Enforcing the 1988 Basel Capital Requirements: Did it Curtail Bank Credit in Emerging Economies? Economic Notes. Review of Banking, Finance and Monetary Economics, 30, November, 399-419. http:// dx.doi.org/10.1111/1468-0300.00065. 
Choi, G. (2000). The Macroeconomic Implications of Regulatory Capital Adequacy Requirements for Korean Banks. Economic Notes, 29(1), February, 111-143. http:// dx.doi.org/10.1111/1468-0300.00026.

Dell'Ariccia, G., Laeven, L., \& Suarez, G. (2013). Bank Leverage and Monetary Policy's Risk-Taking Channel: Evidence from the United States. IMF Working Paper, WP/13/143, June. http://dx.doi.org/10.5089/9781484381137.001.

Demchuk, O., Łyziak, T., Przystupa, J., Sznajderska, A., \& Wróbel, E. (2011). Mechanizm transmisji polityki pieniężnej w Polsce. Co wiemy w 2011 roku? Raport, Instytut Ekonomiczny Biuro Badań, grudzień.

Economic Planning Agency (1998). White Paper on Japanese Economy 1997-1998, Ministry of Finance Printing Bureau, December.

Farhi, E., \& Tirole, J. (2009). Collective Moral Hazard, Maturity Mismatch and Systematic Bailouts. NBER Working Paper Series, 15138, July.

Furfine, C. (2001). Bank portfolio allocation: The impact of capital requirements, regulatory, monitoring, and economic conditions. Journal of Financial Services Research, 20, 33-56.

Hancock, D., \& Wilcox, J.A. (1992). The Effects on Bank Assets of Business Conditions and Capital Shortfalls. Credit Markets in Transition. Federal Reserve Bank of Chicago, May, 502-520.

Hancock, D., \&Wilcox, J.A. (1997). Bank Capital, Non-bank, Finance, and Real Estate Activity. Journal of Housing Research, 8, 75-105.

Herrera, H.V., Betancourt, Y.R., Varela, C., \& Rodríguez, N. (2010). Effects of reserve requirements in an inflation targeting regime: the case of Colombia. BIS Working Papers, 54, 133-169.

Ito, T., \& Nagataki Sasaki, Y. (1998). Impact of the Basle Capital Standard on Japanese Banks' Behavior. NBER Working Paper Series, 6730, September.

Jackson, P., Furfine, C., Groeneveld, H., Hancock, D., Jones, D., Perraudin, W., Radecki, L., \& Yoneyama, M. (1999). Capital Requirements and Bank Behaviour: The Impact of the Basle Accord. Basle Committee on Banking Supervision Working Papers, 1, April.

Keys, B.J., Mukherjee, T., Seru, A., \& Vig, V. (2008). Did Securitization Lead to Lax Screening? Evidence from Subprime Loans. Centre for Economic Performance, January. http://dx.doi.org/10.2139/ssrn.1108677.

Kokoszczyński, R. (red.) (1999). Mechanizm transmisji impulsów polityki pieniężnej: przegląd głównych teorii oraz specyfika transmisji w Polsce. Materiały i Studia, 91, NBP, Warszawa.

Maddaloni, A., \& Peydró, J.L. (2010). Bank Risk-Taking, Securitization, Supervision and Low Interest Rates. Evidence from the Euro Area and the U.S. Lending Standards. European Central Bank Working Paper Series, 1248, October.

McCarthy, J., \& Peach, R.W. (2002). Monetary Policy Transmission to Residential Investment. Federal Reserve Bank of New York Economic Policy Review, 8(1), 139-158.

Mesquita, M., \& Toros, M. (2010). Brazil and the 2008 panic. BIS Working Papers, 54, 113-120. 
Montoro, C., \& Moreno, R. (2011). The use of reserve requirements as Policy instrument In Latin America. BIS Quarterly Report, March, 53-65.

Peek, J., \& Rosengren, E. (1993). Bank regulation and the credit crunch. Federal Reserve Bank of Boston Working Papers, 93-2, February. http://dx.doi.org/10.1016/03784266(94)00148-V.

Peek, J., \& Rosengren, E.S. (1992). The Capital Crunch: Neither a Borrower Nor a Lender Be. Federal Reserve Bank of Boston, February. http://dx.doi.org/10.2307/2077739.

Peek, J., \& Rosengren, E.S. (1997a). Collateral Damage: Effects of the Japanese Real Estate Collapse on Credit Availability and Real Activity in the United States. Federal Reserve Bank of Boston Working Paper, 97-5, August 26. http://dx.doi.org/10.2139/ ssrn.82728.

Peek, J., \& Rosengren, E.S. (1997b). The International Transmission of Financial Shocks: The Case of Japan. American Economic Review, 87:4, September. http://dx.doi. org/10.2139/ssrn.36583.

Prunanandam, A. (2009). Originate-to-Distribute Model and the Sub-Prime Mortgage Crisis. Working Paper, October 29.

Rajan, R.G. (2005). Has Financial Development Made the World Riskier? NBER Working Paper Series, 11728, November.

Rajan, R.G. (2009). The Credit Crisis and Cycle-Proof Regulation. Federal Reserve Bank of St. Louis Review, 91, September/October, 397-402.

Redo, M. (2013). The Growing Importance of the Risk-Taking Channel in the Process of Transmitting Monetary Policy. Torun International Studies, 1 (6), 13-22, Published online December, 2013. http://dx.doi.org/10.12775/TIS.2013.002.

Tanaka, M. (2002). How do bank capital and capital adequacy regulation affect the monetary transmission mechanism? CESifo Working Paper, 799, October.

Wagster, J.D. (1999). The Basel Accord of 1988 and the International Credit Crunch of 1989-1992. Journal of Financial Services Research, 15, 123-243.

Watanabe, W. (2007). Prudential Regulation, the 'Credit Crunch' and the Ineffectiveness of Monetary Policy: Evidence from Japan. Journal of Money, Credit and Banking, 39, March-April, 639-665.

Zicchino, L. (2005). A model of bank capital, lending, and the macroeconomy: Basel I versus Basel II. Bank of England Working Paper, 270. http://dx.doi.org/10.2139/ ssrn.824729. 